\title{
Consequences of the incident at Novovoronezh NPP in 1985
}

\author{
O. Kochetkov ${ }^{1}$, B. Serebryakov ${ }^{1}$, M. Semenova ${ }^{1}$, E. Ivanov ${ }^{2}$ and A. Shchukin ${ }^{3}$ \\ ${ }^{1}$ Burnasyan Federal Medical Biophysical Centre Federal Medical Biological Agency, \\ 123182, Zhivopisnaya 46 Moscow, Russia \\ ${ }^{2}$ All-Russian Scientific Research Institute for Nuclear Power Plant Operation, \\ 109507, Ferganskaya 25, Moscow, Russia \\ ${ }^{3}$ Novovoronezh NPP, 396072 Novovoronezh, Voronezh Region, Russia
}

\begin{abstract}
In 1985, at Novovoronezh NPP (NVNPP), the leakage occurred of liquid radioactive waste (LRW) from the storage facility No. 2 (SLW-2) into the soil. According to the fulfilled assessments, the total volume of LRW penetrated into the soil was about $480 \mathrm{~m}^{3}$, the total activity of ${ }^{60} \mathrm{Co}$ was $76 \mathrm{TBq}(2050$ $\mathrm{Ci})$ and of ${ }^{137} \mathrm{Cs}-15 \mathrm{TBq}(390 \mathrm{Ci})$. The total activity of other radionuclides was less than $0,037 \mathrm{TBq}(1 \mathrm{Ci})$. The salt contents in LRW were $120-150 \mathrm{~g} / \mathrm{l}$. Thus, ${ }^{60} \mathrm{Co}$ was the main contaminant of the environment.
\end{abstract}

\section{METHODS OF ENVIRONMENTAL INVESTIGATION}

Disadvantages of the design of NVNPP Liquid Waste Storage facility-2 (LWS-2) and the operator's error caused the leakage. This leakage was discovered 02.09 .85 , in the course of water monitoring in observation boreholes, approximately in a half a year after the assumed incident date. The delayed detection of the leakage has decreased considerably the efficiency of works aimed at mitigation of its consequences by means of underground water pumpdown from the observation boreholes during the period from October 1986 till February 1991.

Conventional environmental examinations being performed at NVNPP could not assure quite representative radiation monitoring of contamination, so the special "Regulation of the comprehensive monitoring of the radioactive contamination area near the NVNPP LWS-2" has been developed. This regulation served as the supplement to the routine regulation No. 55-ORB. The «Regulation...» establishes types and the extent of the environmental monitoring at the area under contamination following the incident of 1985. The NVNPP Laboratory of the external radiation monitoring (LERM) performs such monitoring.

- The «Regulation ... » envisages the following type of monitoring:

- monitoring of ${ }^{60} \mathrm{Co}$ and other man-made radionuclide contents in ground waters in boreholes located within the health protection zone and on the industrial site;

- monitoring of ${ }^{60} \mathrm{Co}$ and other man-made radionuclide contents in superficial waters in the channel to the fish farm, in the waste channel, in Don River, in the mouth of the waste channel and in the fish farm ponds;

- monitoring of ${ }^{60} \mathrm{Co}$ and other man-made radionuclide contents in bottom sediments and in water plants in the channel to the fish farm, in Don River and in the fish farm ponds;

- monitoring of ${ }^{60} \mathrm{Co}$ and other man-made radionuclide contents in a fish in Don River and in the fish farm ponds;

- monitoring of ${ }^{60} \mathrm{Co}$ and other man-made radionuclide contents in the soil of the flood-lands of Don River; 
- dose rate measurements in the sampling points within the boreholes and in the superficial ponds, as well as on the bottom of Don River, on the bottom of the channel to the fish farm, on the bottoms of the fish farm ponds, in the bottom sediments of the waste channel mouth and in other points;

- gamma logging measurements in the observation boreholes;

- the regulation operation include also measurement of the water level in the boreholes, measurement of water flow (discharge) in the channels and determination of the water level in Don River during sampling.

This «Regulation... » is being changed annually depending on the findings obtained. For example, initially, monitoring of radionuclides contents in the basic foods has been introduced into the «Regulation... », but ${ }^{60} \mathrm{Co}$ was being detected only in a fish, therefore, other foodstuffs has been excluded from the «Regulation... » later. ${ }^{60} \mathrm{Co}$ inflow in Don River and in the fish farm ponds is being assessed in terms of monitoring results.

\section{RESULTS AND CONCLUSIONS}

Today, almost all ${ }^{137} \mathrm{Cs}$ activity is being localized in the place of leakage - in the unsaturated zone under LWS-2. Only in the boreholes nearby LWS-2, ${ }^{137} \mathrm{Cs}$ activity is higher than the intervention level (IL) determined according to the Russian Norms of Radiation Safety (NRB-99). ${ }^{90} \mathrm{Sr}$ activity is 7 times lower than IL, while that of plutonium isotopes is about three orders of a magnitude lower than IL. Intervention level is a radionuclide activity in water, which causes the exposure of $0.1 \mathrm{mSv} / \mathrm{year}$ effective dose at 7301 water consumption in a year; the level of a liquid ascription to the radioactive waste category in Russia is $10 \mathrm{IL}$.

Distribution of ${ }^{137} \mathrm{Cs}$ in groundwater is not normal: it presents in the place of groundwater discharge in Don River, at the distance of about $700 \mathrm{~m}$ from LWS-2, where its activity in the groundwater is hundreds times higher than activity in Don River, but 20 times lower than IL.

${ }^{60} \mathrm{Co}$ activity in the groundwater exceeds the level, which permits to consider this water as LRW; such is the case mainly near LWS-2, where ${ }^{60} \mathrm{Co}$ activity is highest, even now. Migration rate of ${ }^{60} \mathrm{Co}$ anion was being determined on the base of ${ }^{60} \mathrm{Co}$ activity measurements in the boreholes, this rate equals to the real filtration rate of ground waters. This rate is 30-40 m/year near LWS-2, and increases with the distance to Don River. The average migration rate at the area from LWS-2 to the waste channel mouth is about $70 \mathrm{~m} /$ year.

It has been determined that ${ }^{60} \mathrm{Co}$ presented in ground waters in two main forms: in sorbable cation and non-sorbable anion forms, in compound with ethylene-diamine-tetra-acetic (EDTA) acid. Near LWS-2, ${ }^{60} \mathrm{Co}$ is mainly in the cation form, while in the ground waters being discharged into Don River ${ }^{60} \mathrm{Co}$ is mainly in the anion form.

Contamination of bottom sediments is being registered in the waste channel mouth of the NVNPP first stage, as well as in bottom sediments of Don River approximately $350 \mathrm{~m}$ higher than the mouth. Activity of ${ }^{60} \mathrm{Co}$ in the bottom sediments of the waste channel mouth is several times higher than the activity level, which permits to consider these sediments as solid radioactive waste (SRW), ${ }^{60} \mathrm{Co}$ activity in the bottom sediments of Don River is lower than SRW level.

${ }^{60} \mathrm{Co}$ is being registered in trees near of Don River, in seaweeds, and in some fish samples from Don River. The traces of ${ }^{60} \mathrm{Co}$ are being registered in the bottom sediments of Don River at the distance of $280 \mathrm{~km}$ from NVNPP.

Assessments of the public effective dose, carried out on the base of ${ }^{60} \mathrm{Co}$ content in fish, give a trivial value, which is less than $1 \mu \mathrm{Sv}$ /year. This value is tens times lower than quota of $10 \mu \mathrm{Sv} /$ year, authorized for the public exposure due to radioactive waste, according to the Russian Main Radiation Protection Rules (OSPORB-99).

${ }^{60}$ Co inflows in Don River were being registered at NVNPP in 1995 by the seaweeds contamination. Assessment of ${ }^{60} \mathrm{Co}$ inflow in Don River made in 2001-2003, gives value lower than $0.074 \mathrm{TBq} / \mathrm{year}$ (2 Ci/year), at permissible discharge of $0.63 \mathrm{TBq} /$ year $(17 \mathrm{Ci} /$ year). 
Up to now, NVNPP has completed some remedial and protective actions, for example contaminated bottom sediments of the waste channel mouth have been covered with a coarse rock material. This has led to reduction of the exposure dose rate (EDR): before covering the EDR value was 10-28 times higher than the authorized value in the health protective zone of the NPP $(2,5 \mu \mathrm{Sv} / \mathrm{h})$, while after covering, the EDR value is not higher than $1 \mu \mathrm{Sv} / \mathrm{h}$, i.e., the EDR value became tens times lower. 
